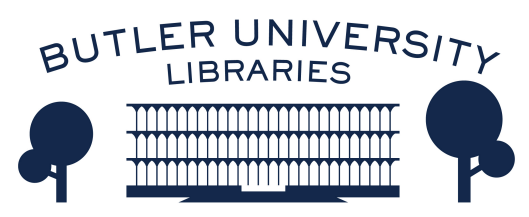

Journal of Hindu-Christian Studies

Volume 16

Article 10

January 2003

\title{
Meeting 'the Mother Who Takes Across': Christian Encounters with the Fierce Goddesses of Hinduism
}

Rachel Fell McDermott

Follow this and additional works at: https://digitalcommons.butler.edu/jhcs

Part of the Religion Commons

\section{Recommended Citation}

McDermott, Rachel Fell (2003) "Meeting 'the Mother Who Takes Across': Christian Encounters with the Fierce Goddesses of Hinduism," Journal of Hindu-Christian Studies: Vol. 16, Article 10.

Available at: https://doi.org/10.7825/2164-6279.1299

The Journal of Hindu-Christian Studies is a publication of the Society for Hindu-Christian Studies. The digital version is made available by Digital Commons @ Butler University. For questions about the Journal or the Society, please contact cbauman@butler.edu. For more information about Digital Commons @ Butler University, please contact digitalscholarship@butler.edu. 


\section{Meeting 'the Mother Who Takes Across': Christian Encounters with the Fierce Goddesses of Hinduism}

\section{Rachel Fell McDermott Barnard College}

THIS essay revolves around a simple question: what does Hindu-Christian dialogue look like from the Christian side when the Hindu side is represented by Saktism? Or, how do Christians, whether Protestant or Catholic, react and what do they learn when the Hindus they encounter worship a supreme female divinity who is both compassionate and wrathful, whose cult is often associated with blood sacrifice, whose philosophical underpinnings tend to be monistic, and some of whose devotees have been involved in esoteric, often sexual Tantric rites? Where are the cross-overs, the bridges to understanding?

I ask this question about the relationship between Christians and Saktas because of who I am and what I study. As an Episcopalian who has spent the last fifteen years researching the Bengali devotional traditions to the goddesses Kali and Durga, I find this question at the center of my theological thinking. How is my academic immersion in the study of powerful Hindu goddess figures affecting my Christian spiritual life?
By "Saktas" here I do not mean Hindus of a Vaisnava turn of mind, that is, Hindus for whom the goddess is Visnu's consort Sri or Laksmi in some form, a goddess who mediates or intercedes with her more powerful Lord. Rather, I. concentrate on Kali and Durga, goddesses who, although typically paired with Siva, assume the dominant role in the relationship, and can themselves grant liberation and material benefits. Iconographically, both are depicted as saving the world from demons: Durga sits astride her lion mount, piercing the chest of a buffalo-demon named Mahisa with her lance. The "Devi-Mahatmya," the sixth-century Sanskrit text which first tells of her exploits, recounts that although beautiful to look at, her visage and the weapons in her sixteen hands strike terror in her foes. Kali, the goddess who beams forth from Durga's angry forehead to help her battle evil, is even more fear-inspiring: her typical iconography portrays her standing on her husband Siva on a cremation ground or battlefield after she has just run amuck killing demons; she wears a necklace of cut

Rachel Fell McDermott is Associate Professor and Chair of the Department of Asian and Middle Eastern Cultures at Barnard College, where she has been teaching since 1994. She received her Ph.D. from the Committee on the Study of Religion at Harvard University in 1993, and is a specialist on Indian, specifically Bengali, religious traditions. Her publications include: Mother of My Heart, Daughter of My Dreams: Kali and Uma in the Devotional Poetry of Bengal (New York: Oxford University Press, 2001), Singing to the Goddess: Poems to Kali and Uma from Bengal (New York: Oxford University Press, 2001), and Encountering Kali: In the Margins, At the Center, In the West, edited with Jeffrey Kripal (Berkeley: University of California Press, 2003). 


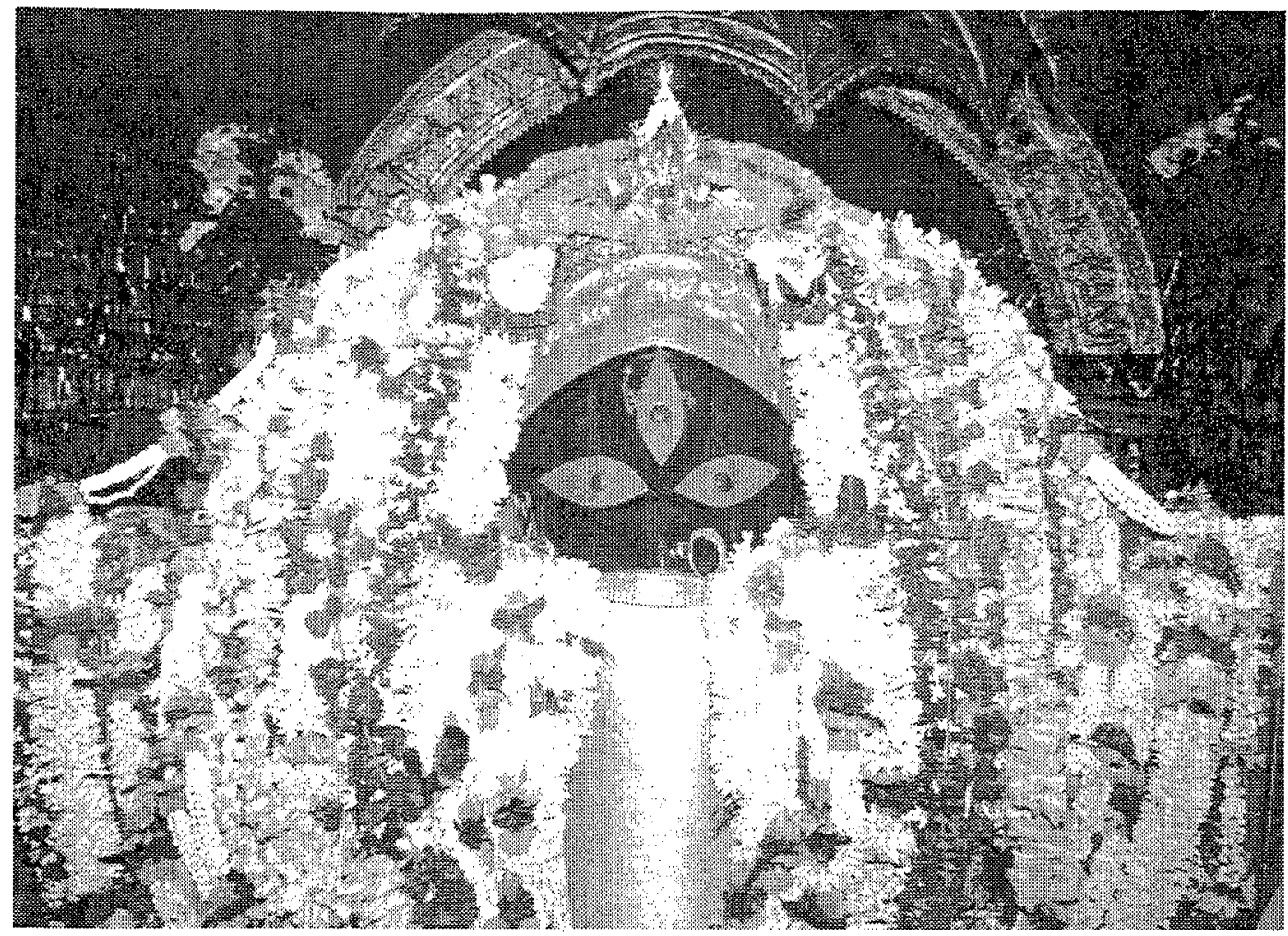

heads, a mini-skirt of arms sewn together at the elbows, and children's corpses for earrings. She is often, however, shown smiling, and two of her four hands betoken boons and fearlessness. Both of these goddesses are the center of a popular cult in Bengal and Assam, where they receive blood sacrifice, all year around but especially during their annual festivals. It is this part of eastern India, where I have done my fieldwork and where Christian missionaries made quite an impact in the first half of the nineteenth century, that is the focal point of this essay. These same questions could also arise in other parts of India with large numbers of Saktas and Christians, particularly Tamilnadu and Kerala, but $I$ do not address them here.

In what follows I present a historical survey of Christian attempts to effect a rapprochement with Saktism, noting the absences, peculiarities, and challenges of these attempts. The other half of the dialogue - Sakta feelings about Christianity is of equal interest, but not my subject for the present.

\section{Not Seeking Saktas: Crossing Elsewhere Along the Shore}

The most extraordinary surprise that awaits anyone investigating this topic is how little anyone has thought about it. Christians who have wanted to engage in dialogue with Hindus have typically found two other avenues for theological exploration: Vedantic philosophy and Vaisnava devotionalism. Saktism enters nowhere not even in the Bulletin of the Society for Hindu-Christian Studies. Some of the most famous Christian exponents, intellectually and practically, of Hindu-Christian dialogue - Bede Griffiths (1906-1993), Raimundo Panikkar (b. 1918), and Swami 
Abhishiktananda (1910-1973) - have found the philosophical monism of Vedantic thought to provide the best links to Christian ideas about God. These theologians elucidate Christian notions of the Trinity and the functioning of the Holy Spirit by plumbing the Vedanta Sutras; the philosophical treatises of Sankara, Ramanuja, and Madhva; and the Upanisadic concepts of atman (self) and Brahman (Absolute). ${ }^{1}$

The other route to dialogue, perhaps even more well traveled, involves not philosophy but piety. Generations of Christian missionaries and scholars have found in Hindu bhakti poetry traditions, especially those centered around Visnu and Krishna, analogs for Christian beliefs: Visnu incarnates; his incarnations sometimes suffer and/or trick demons; ${ }^{2}$ he offers, like a father, forgiveness and grace; he is willing to stoop low to win the souls of the trapped; and his consort, Sri, like the Virgin Mary, acts as a maternal mediator between the devotee and God. Mathew Muttumana, an Assamese Christian writing in the mid-1980s about the possibility of dialogue between Christianity and Hindu traditions, concludes that it is Vaisnavism, not Saktism, that offers the greatest resources; Vaisnava bhakti and Christianity "teach with astonishing similarity, that [the] justification and salvation of a man is merely an act of divine Grace which demands no precondition." ${ }^{3}$ Many Christian converts in Bengal were first Vaisnava; this background seems to have prepared them theologically to accept Christian doctrines and ideas. ${ }^{4}$

\section{Throwing Stones Across the River: A History of Christians Disgust}

Why such silence or lack of engagement with Saktism on the part of Christians interested in inter-religious dialogue? The most important reasons are historical: colonialism and missions. Simply put, most Christian observers in India in the late eighteenth and nineteenth centuries, whether scholars, missionaries, or European travelers, found the goddess worship they encountered off-putting. This was true whether they were commenting on idolatry in general, on the Kali of the famed temple in Calcutta, Kalighat, on blood sacrifices within temple precincts, or on the supposedly licentious practices of goddessworshiping Tantric votaries.

"In the evening," wrote Fanny. Parks in her travelogue from 1850, "I drove to see the far-famed Bengalee idol, Kala Ma, to which, in former times, [human] sacrifices were publicly offered. The temple is at Kala Ghat, about two miles from Calcutta. The idol is a great black stone cut unto the figure of an enormous woman, with a huge head and staring eyes; her tongue hangs out of her mouth, a great broad tongue, down to her breast. The figure is disgusting." ${ }^{15}$ The sacrifice of chickens, goats, and even buffalos has horrified onlookers since William Ward's succinct summary of his experiences at Kalighat in 1811: "The bleating of the animals, the number slain, and the ferocity of the people employed, actually made me unwell, and I returned about midnight filled with horror and indignation." ${ }^{16}$ Geoffrey Parrinder, in his book Avatar and Incarnation, echoes this sentiment as recently as 1970: "The Gita, the stories of Ràma and Krishna, the songs of the medieval mystics, the monotheism of Saiva Siddhànta, all lead men to God. But there is also a dark side to Hinduism, haunted by demons, divided by caste prejudice, and married by blood sacrifices such as those still practiced by the followers of Kala."

Not surprisingly, this critique of "degraded" Sakta tradition was also asserted, sometimes even more vehemently, by Indian converts. Krishna Mohan Banerjea vowed in 1851 to fight "the idolatry and heroworship of the Puranas and Tantras, and all the moral, social and spiritual evils which have accumulated in the country by the prevalence of those monstrous errors and 
ungodly practices." ${ }^{18}$ Lal Bihari De (18261894) decried Durga's annual festival as a "national apostasy," a "pitiful prostitution of those powers with which God has endowed man." 9 These voices are still with us today, either in the form of tracts by Indian Christians ${ }^{10}$ or diatribes by foreign Christian missionary groups.

From the historical perspective, Saktism was also at a disadvantage in terms of its potential for inter-religious dialogue because of the use to which it was put by Indian nationalists in the late-nineteenth and early twentieth centuries. The puissant, demoneating deities Kali and Durga became reservoirs for and icons of anti-British feeling. Indian nationalists exhorted their contemporaries to offer Kali the blood of white goats, to take inspiration from her bloody rampage on the cremation ground, newly reinterpreted as the pillaged nation of India, and to consider her as a Mother calling her children to self-sacrifice ${ }^{.11}$ This emergent nationalism, linked to a Sakta tradition with deep roots in Bengal, made conversions - and hence inter-religious dialogue - difficult after the mid-nineteenth century. ${ }^{12}$

In spite of this rather dismal picture of obstacles and historical pitfalls, there have been some rather sympathetic Christians who have tried to approach Saktism with an open mind. Sir John Woodroffe (18651936) is perhaps the premier example: a high court judge resident in Calcutta in the first two decades of the twentieth century who studied Tantra with several Bengali teachers and who made the defense and rehabilitation of goddess worship his mission. ${ }^{13}$ Others of this breed include Edward Thompson and Arthur Spencer, who translated in 1923 the first anthology of devotional poetry to Kali and Durga; ${ }^{14}$ and Ernest Payne, who in The øàktas: An Introductory and Comparative Study from 1933 tries to find "genuine piety" in the Sakta tradition. ${ }^{15}$ Although some modern Christians are following in the footsteps of these early pioneers, not all would-be dialoguers find the goddess traditions easy to approach. Admitted Hans Kung about Saktism and Tantrism: these systems are "extraordinarily alien to Christians, more alien than anything we have met thus far in Buddhism or Hinduism." 16

Beyond the historical accident of Bengal's prominence in British India, there are additional, purely conceptual reasons for Christians' suspicion of Saktism as a conversation partner. Many of the typical bridges - those present when Christians talk to Vaisnavas, for instance - are lacking here. Kali and Durga are not perceived as incarnating periodically for the good of humanity. Moreover, there is little in Saktism that could be construed as a parallel to the Christian ideas of atonement or divine suffering. ${ }^{17}$ Bengali converts such as Krishna Mohan Banerjea found the atonement a particular stumbling block when he was moving toward accepting Christ, as it seemed so foreign to his way of thinking. ${ }^{18}$ The Goddess can cause us, through her power of illusion, to fall into error or to sin, and insofar as she is the Matter out of which all is created she can be said to share that error or sin and to suffer along with her creation. However, she saves us from this directly through grace and enlightenment, not through a cosmic act of substitutional expiation, and there is nothing comparable in her mythology to Jesus' "agony of blood and sweat," the self-giving surrender on a cross. ${ }^{19}$ The blood sacrifice that occurs in many goddess temples throughout India is given to slake her bloodlust, to plead with or thank her for a boon. Sacrifice is something humans do. Kali is never the vicarious victim.

\section{Stringing Footbridges for the Few}

In spite of the dismal picture of ChristianSakta interactions presented thus far, it is nevertheless true that there have been some Christian attempts at theological crossings. Most of these have been rather minor and are in need of further exploration. One, 
however, promises fruitful exchange. First I describe the less prominent, less stable, bridges.

Sakti, or the energy of the Goddess, the female life-power that courses through creation, is perhaps the most important theological concept of the goddessvenerating Hindu traditions. It is no surprise, therefore, that among those very few Christians who think about Saktism, Sakti is addressed and a Christian place somehow made for it. The most common linkages are the Virgin Mary and the Holy Spirit. But while Mary shares the majesty of Sakti in her exalted roles as Mother of God, Bride of Christ, Intercessor, and Queen of Heaven, and while she puts down the serpent with her foot and has the ability in her miraculous appearances to act as a local protectress, she has little of the ultimacy, ambivalence, or dark sides associated with Kali or other Hindu Sakta goddesses. Besides, Mary "works" as an analog to Sakti only for Catholics. ${ }^{20}$

The Holy Spirit may be a better candidate, especially since Sakti in current Indian Christian usage is normally used for the power of the Holy Spirit. . Swami Abhishiktananda formally identifies Sakti with the Spirit, describing its function as both the self-emptying, kenotic power causing the universe to unfold, and the power that brings all of creation back to the Son and the Father. ${ }^{21}$ Two South Indian converts from the first half of the twentieth century, P. Chenchiah (1886-1959) and V. Chakkarai (1880-1958), also advocate an indigenized understanding of the Holy Spirit through the concept of Sakti. ${ }^{22}$ Closer to home, Diana Eck, in Encountering God: A Spiritual Journey from Boseman to Banaras, states that "the Hindu sense of Shakti has time and again steered me toward a larger understanding of the Holy Spirit." She outlines three ways in which this has happened for her: the sense of magnetism or being alive that Sakti implies; Sakti's link with Nature; and Sakti's presence in death. The sanctuaries of the Goddess in India have "challenged me to be open to the presence and power of God in places where it is uncomfortable to be, in places that are frightening, in places where we confront the skulls." In this vein, she describes the comfort and sustenance of the Holy Spirit in helping her to brave the agonizing death by torture in prison of her brother. ${ }^{23}$

Another approach to finding Christian analogs for important Sakta concepts focuses on the Hindu idea of Prakriti, or Primordial Matter. This too, in Sakta theology, is identified with Sakti and her manifestations as particular goddesses; in Sakta accounts of creation, it is Matter which ensnares, entices, lures the Purusa or Spirit into creative activity. As such, the Hindu Goddess represents or encompasses all of material creation, and is, in Christian terms, the matrix for the Holy Spirit. In spite of the fact that there is no comparable idea in Christianity for the identification of the divine with matter, ${ }^{24}$ this conception has helped certain Christians. One, David Kinsley, a noted scholar of the goddess Kali, was diagnosed with inoperable lung cancer in January of 2000 and given three months to live. In an interview videotaped one month after his diagnosis, he explained that the idea of the earth as the body of the Goddess, though not Christian, was helping him to accept his death with equanimity: he found comfort in thinking of his ashes merging back into the Mother.

A third attempt at bridge-building is less philosophical and more theological, and centers on the implications of Kali's image and perceived personality. Emest Payne, always trying to find a way to talk himself out of his gut feelings of discomfort with Saktism, refers to Rudolf Otto's sympathetic reading of Hindu goddess worship, which helped him as well view it with sympathy. ${ }^{25}$ In his famous book, The Idea of the Holy, Otto (1869-1937) refers to Tantra, and the worship of some forms of Siva and Durga, as exemplifying the "mysterium tremendum," the "numinous," the fascinating, and the Wholly Other. ${ }^{26}$ 
Similarly, a Bengali Brahman Christian convert, Joguth Chunder Gangooly, who spent time in Boston and even attended lectures at Harvard Divinity School in the mid-nineteenth century, tried to translate the frightening aspect of the Goddess into a Christian theological framework of God's mercy and justice: "The image of Kalee is a Hindoo illustration of the doctrine of retribution. While two of the hands of the goddess are punishing sin, the other two, at the same time, are offering peace to the deserving. ${ }^{27}$ In the early twentieth century, Ernest Wood made the same point about Kali's fierceness: she is a theological reminder of reverence for God in his destructive aspect. ${ }^{28}$

\section{The Overpass of Devotion}

The "favorite" crossing point for Christians to the further shore of Saktism - if one can use such terminology for this unpopular endeavor - is the goddess-centered bhakti poetry of Bengal, associated with the name of Ramprasad Sen (ca. 1718-1775), the first and best of all the poets in the genre. Ramprasad's poems, and those of his contemporaries and followers, became available in English translation from the beginning of the twentieth century, first through the narrative accounts of Ramakrishna's life and then through the anthology collected by Thompson and Spencer in 1923. Christians writers fall upon these poems with evident relief, as if to say, "at last we have found something familiar, something redeeming in this Sakta tradition." Thompson himself comments, "the better side of øaktism is the one which is generally present in Ramprasad," as he leaves behind the "cruel, lustful side of Tantric worship." ${ }^{29}$ Payne likens Ramprasad's diatribes against animal sacrifice to the Hebrew prophets' tirades against "the savage cults of Canaan," and he compares the tone of the poetry to the laments of Job and Jeremiah, concluding that this poetry is the healthy-minded strain that may yet rescue the Sakta tradition. ${ }^{30}$

Indeed, there do appear to be a great many possibilities regarding the usefulness of this tradition for attempts at HinduChristian bridge-building.

For instance, the poets approach Kali like children before their mother and throw themselves upon her mercy. She is committed to the human race, compassionate, able to conquer death, gracedispensing, and powerful over sin, the sense of which is-palpable in the poetry. ${ }^{31}$

Supreme Savior of Sinners, awarding the fruit of highest bliss, grant the shade of Your feet to this very wretched one,

Wife of øaikara.

In Your great goodness

be merciful to me,

Deliverer,

Ma:

I've committed sins,

I've got no merit,

and as for prayer

I'm empty.

Take Your form Tara

and rescue me,

Mother of the Universe.

Your feet are my boat;

They carry me over the sea of becoming.

Be gracious to Prasad,

Bhava's housewife.

Ramprasad Sen

The poets also get saucy and pungent with their deity, and in language reminiscent of the Psalmist berate her for her neglect, before concluding with a humble supplication or an assertion of faith:

Can someone

called Daughter of a Stone

have compassion in Her heart? 
If She weren't pitiless, could

She kick Her husband in the chest?

The world knows You

as The Compassionate, but

there isn't a trace of compassion

in You. You wear a necklace

of heads, cut

from other mothers' sons!

The more I cry Ma Ma!

the more

though I know You hear me

You don't listen.

Prasad gets kicked

for no reason. Still

he calls out

\section{Durga!}

\section{Ramprasad Sen}

Some of the poets delight in describing Kali's appearance - her bloody, horrifying visage - and then sweeten it, such that one is forced to see beauty in what is fearful.

Who is this

delighting in war

dancing naked with witches

on the battlefield?

The rays of the morning sun

and ten moons

glisten in Her toenails.

Amazing! Her body

black as clouds

pierces darkness with its sheen, and Hara, a cadaver, is fallen at Her feet.

There too lie

brilliant reds and whites, intoxicating

java and bilva flowers, heaped by the immortals.

She's got hair blacker than clouds, eyes shot with the lotus's red, a distended, dangling tongue,

and a face a horrible face

with streams of blood

oozing from Her lips.

The earth trembles at Her arrogance.

Suddenly a dreadful shriek,

a blast of fire - lightning explodes from $\mathrm{Her}$

eyes

to dance playfully

in the sparkle of Her teeth.

This is a frightful sight; it can make you fear.

But for a devotee

She's a blessing who takes away fear.

Her Lowly One says: This is no ordinary being

but the risen form

of the Goddess whose Essence is Brahman.

\section{Raghunath Ray}

For me, what is attractive for the purpose of dialogue in these poems is not the specific beliefs about karma, samsara, transmigration; and liberation; after all, there is plenty here that would appear foreign to a Christian. What is appealing is the tone: intimacy, the daring, the familial parentchild relationship, the expression in homey language and metaphor of the experience of living with a powerful, unpredictable, sometimes present sometimes absent deity, whose loving kindness one nevertheless wants to affirm. One can see why Christians have been so willing to forge links with bhakti groups, particularly Vaisnava but also Saiva: there is something we recognize here in the frank openness of self-disclosure before a merciful God.

From the vantage point of feeling, then, these poems seem familiar to us, even though Ramprasad and his poetic contemporaries are more irreverent than we are used to. Do we sing hymns in which we challenge God's sense of justice, or teasingly castigate Jesus for his unkind behavior to his 
mother when he asked, "who is my mother, who are my brothers?" (Matt. 12:48). Perhaps we do not go this far. Nonetheless, Christians of a devotional frame of mind will experience in this Kali-poetry something touching, something recognizable in terms of intimacy.

What I personally find so promising about the Sakta bhakti poetry is that it does not allow one to shy away from the goddesses at the center of Sakta religiosity. Musing on the relevance of Sakti to the Holy Spirit, while fruitful philosophically, allows one potentially to bypass Durga, Kali, and other goddesses altogether. Diana Eck and David Kinsley, who are experts on goddess worship, do not divorce Sakti from her manifestations, and this gives them the powerful ability to accept the dimensions of ambivalence and even death in their discussions of Sakti's impact upon them.

Ironically, all of the lessons Christians may learn from Kali and Durga - the acceptance of death, the ability to chide, tease, and complain to God, the confrontation with divine power, and the acknowledgment of what feels like God's ambivalence - may be more ideal than lived, on-the-ground realities, for actual Saktas. Recent studies of Bengali goddessworshippers indicate that most people, like religious folk everywhere, do not aspire to theological complexities in their thinking. For many, Durga and Kali are totally benign Mothers, who would never harm their children, who should be treated with nothing but reverence, and who are not responsible for our worldly sins and errors. What Christians find shocking in the Sakta poetry, therefore, may also be what average Saktas distance themselves from. In his chapter on "Hindu Goddesses and the Blessed Virgin Mary" in Majesty and Meekness: A Comparative Study of Contrast and Harmony in the Concept of God, John Carman wrote, "it is possible that Christian theology as it is experienced by most people is closer to Hindu conceptions than some theologians will admit." ${ }^{12}$ I agree but state the opposite: it is possible that Sakta theology as it is experienced by most people is closer to Christian conceptions than some theologians will admit.

To conclude, Christians and Saktas interested in each other - already an elite undertaking, as we have seen - may build the best bridges to understanding with the fairly ordinary wooden planks of human feeling and desire for depth of relationship with God. Perhaps later, after walking back and forth across the bridge several times, they will begin to think more theologically about the structural grounding on both shores.

\section{Notes}

1. See Bede Griffiths, Vedanta and Christian Faith (Los Angeles, CA: Dawn Horse Press, 1973) and Return to the Center (Springfield, IL: Templegate, 1977); Raimundo Panikkar, The Unknown Christ of Hinduism, $2^{\text {nd }}$ rev. ed. (London: Darton, Longman, and Todd, 1981); and Swami Abhishiktananda, Ascent to the Depth of the Heart, selected and edited by Raimon Panikkar, trans. David Fleming and James Stuart, (Delhi: Abhiskiktananda Society, 1998) and Saccidananda: A Christian Approach to Advaitic Experience (Delhi: Indian Society for the Propagation of Christian Knowledge, 1974).

2. John B. Carman describes Rama's and Sita's suffering as almost sacrificial, and compares Visnu's tricking of the demon Bali to Jesus's outsmarting of Satan. See Majesty and Meekness: A Comparative Study of Contrast and Harmony in the Concept of God (Grand Rapids: Eerdmans, 1994), p. 203. 
3. Mathew Muttumana, Christianity in Assam and InterFaith Dialogue: A Study on the Modern Religious Movements in North East India (Indore: Satprakashna Sanchar Kendra, 1984), p. 253.

4. Antony Copley illustrates this point through discussions of the Kartabhajas, Lal Bihari De, and Kesabcandra Sen. See Religions in Conflict: Ideology, Cultural Contact and Conversion in Late-Colonial India (Delhi: Oxford University Press, 1997), pp. 208-250.

5. Fanny Parks, Wanderings of a Pilgrim in Search of the Picturesque, 2 vols. (London: Pelham Richardson, 1850), 2: 104.

6. William Ward, An Account of the Writings, Religion, and Manners of the Hindoos, 4 vols. (Serempore: Mission Press, 1811), 3: 190.

7. Geoffrey Parrinder, Avatar and Incarnation: A Comparison of Indian and Christian Beliefs (Oxford: Oxford University Press, 1982), pp. 272-273.

8. Copley, Religions in Conflict, p. 227.

9. Lal Behari Day, "The Durga Puja Vacation," ch. 17 of Reflections of my School Days, collected in an anthology edited by Mahadevprasad Saha (Calcutta: Editions Indian, 1969), p. 542.

10. As one of many older examples, see the Bengali Christian convert R. C. Das, who criticizes the Ramakrishna Mission for its allegorizing of the worship of Kali and other Hindu deities. See "Festivals and Gods," pp. 58-60 of R. C.
Das, Evangelical Prophet for Contextual Christianity, ed. H. L. Richard (Delhi: ISPCK, 1995), which originally derived from The Seeker 3, no. 1 (1949).

11. The best source for such language is Valentine Chirol, Indian Unrest (London: Macmillan, 1910). On p. 27, commenting on the revival of Saktism, he observes how "practices which an educated Hindu would have been at pains to explain away, if he had not frankly repudiated them thirty years ago, now find zealous apologists."

12. See Copley, Religions in Conflict, p. 257.

13. The best study of this very significant figure is Kathleen Taylor's Sir John Woodroffe, Tantra and Bengal: 'An Indian Soul in a European Body'? (Richmond, Surrey: Curzon, 2001).

14. Edward J. Thompson and Arthur Marshman Spencer, trans., Bengali Religious Lyrics, фàkta (1923: New Delhi: Sri Satguru Publications, 1985).

15. Payne, The фàktas, p. 2.

16. Hans Kung, Josef van Ess, Heinrich von Stietencron, and Heinz Bechert, Christianity and the World Religions: Paths to Dialogue with Islam, Hinduism, and Buddhism (New York: Doubleday, 1986), pp. 414-415.

17. Siva's voluntary ingestion of poison to save the world is perhaps the closest parallel to Christ's redemptive power. But this is not, strictly speaking, a Sakta narrative. See Robin Boyd, An Introduction to Indian Christian Theology (Madras: The Christian Literature 
Society, 1975), p. 78, and Stephen Neill's Bhakti: Hindu and Christian (Madras, 1974), p. 80 , cited on p. 46 of Copley, Religions in Conflict.

18. Copley, Religions in Conflict, p. 223.

19. Writing about Krishna and Jesus, a contrast that applies also to Kali and Jesus, Bede Griffiths states, "the contrast with Christ's love could not be more striking. The love of God was revealed in Christ not in poetry but in history. It was shown not in ecstasy but in selfgiving to others, in the surrender of his life on the cross. It was shown not in play but in an agony of blood and sweat, not in joy but in suffering. Yet each of these is a genuine revelation." Return to the Center, p. 85.

20. Protestant commentator Ernest Payne notes that both "Mariolatry" and the worship of Sakti represent the incorporation of popular superstition, which "undermines theology"; Payne, The фàktas, p. 126.

21. Abhishiktananda, Ascent to the Depth of the Heart, p. 79.

22. Boyd, An Introduction to Indian Christian Theology, pp. 156158, 176-178, and 241.

23. Diana L. Eck, Encountering God: A Spiritual Journey from Boseman to Banaras (Boston: Beacon Press, 1993), pp. 139, 142, 142-143.
24. For Christians there is only one, real creation that is separate from God; there are no analogies here between the pot and clay, sparks from a fire, and drops in the ocean. See Griffiths, Return to the Center, pp. 53-54, 80-81.

25. Payne, The фàktas, p. 114.

26. Rudolph Otto, The Idea of the Holy: An Inquiry into the NonRational Factor in the Idea of the Divine and its Relation to the Rational, 2nd ed. (London: Oxford University Press, 1958), p. 105.

27. Joguth Chunder Gangooly, Life and Religion of the Hindoos (Boston: Crosby, Nicols, Lee \& Co., 1860), p. 153.

28. Ernest Wood, An Englishman Defends Mother India: A Complete Constructive Reply to "Mother India" (Madras: Ganesh \& Co., 1929), p. 130.

29. Thompson and Spencer, Bengali Religious Lyrics, фàkta, pp. 13 and 22.

30. Payne, The фàktas, pp. 12, 95, and 138-139.

31. These translations come from Rachel Fell McDermott, Singing to the Goddess: Poems to Kàla and Umà from Bengal (New York: Oxford University Press, 2001).

32. Carman, Majesty and Meekness, p. 294. 